\title{
Is Electroconvulsivetherapy (ECT) Effective in The Treatment of Psychosis or Anxiety Disorders? Report of Two Cases
}

\author{
Osman Özdemir ${ }^{1}$, Ekrem Yıllmaz ${ }^{1}$, Ercan Atilla ${ }^{1}$
}

\section{ÖZET:}

Elektrokonvülsifterapi (EKT) anksiyete bozuklug̃u ya da psikozda etkili bir tedavi midir? iki vaka bildirimi

\begin{abstract}
Elektrokonvülsif terapinin (EKT) birincil endikasyonları özellikle melankolik, katatonik veya psikotik özellikli olan depresyondur. Ayrıca EKT akut mani ve psikotik hecmelerde kullanılabilmektedir. Bunlara ek olarak gebelik dönemi psikiyatrik hastalıklarda güvenle kullanılabilen bir tedavi seçeneg̃idir. Fakat EKT'nin anksiyete ve psikotik bozukluklarda etkinliḡi sınırlıdır. Bu çalıșmada EKT'nin etkili olmadıg̃ı iki vaka örneg̃i sunulmuștur.
\end{abstract}

Anahtar sözcükler: elektrokonvülsif terapi, psikoz, anksiyete

Journal of Mood Disorders 2014;4(3):122-5

\section{ABSTRACT:}

Is electroconvulsivetherapy (ECT) effective in the treatment of psychosis or anxiety disorders? Report of two cases

The primary indication for electroconvulsive therapy (ECT) is major depressive disorder, especially with melancholic, psychotic, or catatonic features. In addition, ECT is an effective treatment for symptoms of acute mania and schizophrenia. It is also a good and safe primary treatment option for psychiatric disorders during pregnancy. However, the effects of ECT in both chronic psychosis and anxiety disorders are limited. In this study, we present two cases of patients treated with ECT, which was ineffective.

Key words: electroconvulsive therapy, psychosis, anxiety disorders

Journal of Mood Disorders 2014;4(3):122-5

Department of Psychiatry, Yuzuncuyil
University, Van-Turkey
Yazıssma Adresi / Address reprint requests to:
Osman Özdemir,
Department of Psychiatry, Yuzuncuyil
University, Van-Turkey
Elektronik posta adresi / E-mail address:
drosmanozdemir@yahoo.com
Kabul tarihi / Date of acceptance:
7 Nisan 2014 / April 7,2014
Bag̃ıntı beyanı:
0.0., E.Y., E.A.: Yazarlar bu makale ile ilgili
olarak herhangi bir çıar çatışması
bildirmemişlerdir.
Declaration of interest:
0.Ö., E.Y., E.A.: The authors reported no
conflict of interest related to this article.

\section{INTRODUCTION}

Electroconvulsive therapy (ECT), formerly known as electroshock, is an effective medical procedure in which carefully controlled electrical currents are passed throughout the brain to trigger a brief seizure for the treatment of severe psychiatric disorders. ECT is typically rapid acting and especially used when other treatments are unsuccessful.

\section{Clinical Indications}

The primary indication for ECT is a major depressive disorder, especially with melancholic, psychotic, or catatonic features. It must also be considered when there is an inadequate response to antidepressant drugs and an increased risk of suicide. In addition, ECT is an effective treatmentfor symptoms ofacutemaniaand schizophrenia. It is also a good and safe primary treatment option for psychiatric disorders during pregnancy. Other indications include certain medical and neurological disorders, such as Parkinson's disease, neuroleptic malignant syndrome, and intractable seizure disorder (1-3).

\section{CASE 1}

A 50-year-old man was admitted to the in-patient psychiatric ward at the medical center with the following symptoms; talking to himself, poor self-care, restlessness, frequent hospital admissions, and inappropriate speech. His symptoms started about four years ago, and prior to the onset of his somatic symptoms (within the past few months), he exhibited social withdrawal, reduced speech, nervousness, insomnia, and also telling his family things like: "All of us will die," "We will be ill," "We will be like a stone," and "We are ill." When his somatic symptoms started, he pounded his head, saying: "My head is like a stone," and held his shoulder, saying: "My body is seared." So, he spent a large sum of money going to different general medical practitioners, despite normal laboratory, 
radiological, and physical examinations. He had also been admitted to several psychiatric outpatient and inpatient clinics, where he was treated with a variety of psychotropic drugs. Since his symptoms did not improve, he stopped these courses of treatments. Then, his symptoms have gradually become more severe by time. The patient has no history of substance abuse or mental disorders within the family.

An examination of his mental status revealed the following: very poor self-care; markedly reduced attention and concentration; short responses to our questions; talking slowly and in a low tone; poor thought content; somatic delusions; perseverative speech, such as: "My head is like a stone," "My body is seared"; compulsive behavior; holding his shoulder; dysphoric mood; situational inappropriate smiling; psychomotor restlessness; lack of insight; impaired abstract thinking and social reasoning; decreased appetite; and insomnia.

This patient was considered to be suffering from chronic psychosis due to the four years duration of symptoms, impaired psychosocial functioning, decreased self-care, somatic delusions, talking to himself, inappropriate smiling, poor thought content, perseverative and odd speech, and impaired abstract thinking and social reasoning. The patient was given risperidone ( $4 \mathrm{mg} /$ day) and lorazepam ( $2 \mathrm{mg} /$ day). Then, the dose of risperidone was gradually increased to $8 \mathrm{mg} /$ day due to the persistence of his symptoms. At the end of four weeks, there was no clinically significant difference in the patient. The dose of risperidone was decreased and ECT was started due to recurrent hospitalization, various pharmacotherapeutic agents which were used in the treatment and severe disease manifestation. After the first session, he appeared relaxed. However, six treatment sessions of ECT could not alleviate his psychotic symptoms. On the contrary, the symptoms of psychomotor restlessness, dysphoric mood, and poor self-care increased. In addition, the patient's cognitive functions were impaired. ECT and risperidone were discontinued, and $4 \mathrm{mg}$ /day of pimozide were started. Magnetic resonance imaging (MRI) was performed; however, it revealed no abnormalities. Patient adaptation to service was more difficult; he entered other patients' rooms, smelled awful, and transferred to another inpatient psychiatric hospital.

\section{Discussion 1: Is ECT effective for psychosis?}

Although ECT was first introduced for treating psychosis, it is now a common treatment for mood disorders. In fact, the findings suggest that early cases responding to ECT may have been patients with catatonia, which is more frequently associated with mood disorders (4). ECT alone has also been shown to be less effective than antipsychotics in patients with psychosis (5).The American Psychiatric Association Committee on ECT recommended that ECT is effective for psychotic exacerbations or when affective symptomatology is prominent in schizophrenic patients. However, the committee does not recommend its use for negative symptoms. On the other hand, the National Institute for Clinical Excellence in the United Kingdom does not recommend the use of ECT for schizophrenia, except for catatonic features $(4,5)$. In our case, ECT was used for treatment resistance to pharmacotherapy, but it was not effective in treating psychotic symptoms, including somatic delusions, withdrawal, poor self-care, impaired social functioning, and inappropriate affect. Also, functional and cognitive impairment, poor self-care, and disorganization were worsened by ECT. This result suggested that ECT seems not to be effective in patients with chronic psychosis.

\section{CASE 2}

A 64-year-old man was referred to a university hospital psychiatric clinic for complaints of restlessness, reluctance, averseness, insomnia, suicidal ideas, and a suicide attempt. These symptoms had started about seven months previously after psychosocial stress related to his large family, and their features had gradually increased, especially over the previous few weeks. They had worsened for several days, especially the psychomotor restlessness, and he had attempted suicide by hanging before admission. He had been admitted to several outpatient clinics and had taken a variety of psychotropic drugs, such as venlafaxine, paroxetine, sulpiride, risperidone, and diazepam. Certain medications provided minimal benefits, especially the diazepam, but due to the continuation of his complaints, he had given up this treatment. The patient had no history of substance abuse, but recently he had started smoking a pack of cigarettes a day. 
The mental status examination revealed impaired attention and concentration, significant restless activity, intense feelings of anxiety and tension, rapid breathing, tense muscles, knee joint pain, poor self-care, a depressive and dysphoric mood, sleep problems, including restless sleep or the inability to sleep well at night, and decreased appetite. Also, he felt guilty about his family issues and had suicidal thoughts, but he sought anxiety relief remedies.

Because of his suicidal ideation, recent suicide attempt, resistance to treatment, and depressive symptoms, ECT was performed in three sessions. After the first session, he appeared relaxed. However, after second and third sessions of ECT, his anxiety was exacerbated, he had symptoms of akathisia, dysphoric mood, irritability, and his sleep problems increased. He started to hit his hand and his head against the wall due to anxiety. The patient's symptoms were significantly reduced by escitalopram $20 \mathrm{mg} /$ day, mirtazapine $30 \mathrm{mg} /$ day, diazepam $10 \mathrm{mg} /$ day, and amitriptyline $50 \mathrm{mg} /$ day at the end of five weeks.

\section{Discussion 2: Is ECT effective for anxiety disorders?}

Depression, agitated depression, and primarily psychotic depression were the differential diagnosis of this patient. Therefore, ECT was considered as one of the treatment options. Whatever the diagnosis, the disturbance was characterized by symptoms such as psychomotor agitation, dysphoric mood, and severe anxiety. But, ECT was not effective in this case; moreover it lead to increased anxiety.

Despite many possible mechanisms that are proposed to explain how ECT works, it is still unclear how it exactly functions. The neurochemical theories to account for the effects of ECT in the treatment of depression suggest that the therapeutic effects of ECT are associated with alterations of different neurotransmitter systems,

\section{References:}

1. Burke D, Shannon J, Beveridge A. Electroconvulsive therapy in a 97-year-old woman. Australas Psychiatry. 2007;15:427-30.

2. George K. Electroconvulsive therapy manual licensing, legal requirements and clinical guidelines 2009, Victoria Government Department of Human Services, Melbourne. including the noradrenerjic, serotonergic, and gammaaminobutyric acid (GABA) systems that have all been involved in the neurobiology of anxiety disorders $(6,7)$. However, there is as yet insufficient data to support the use of ECT for primary anxiety disorders.

ECT induced generalized seizures are characterized by hypersynchronous paroxysmal cortical discharge with the predominance of excitatory synaptic conductance in the brain (8). The GABA hypothesis of epilepsy implies that a marked reduction of GABAergic inhibitory transmission results in epilepsy (9). GABA is quantitatively the most important inhibitory neurotransmitter in the central nervous system (CNS). The intrinsic ongoing activity patterns and excitability of cortical neurons are regulated by the interaction between glutamatergic and GABAergic neurons. If the balance swings in favor of GABA, then sedation, anticonvulsant activity, as well as muscle relaxation appear, while nervousness and anxiety are reduced. On the otherhand, an attenuation of the GABAergic system results in arousal, anxiety, restlessness, insomnia, and exaggerated reactivity, as seen in the above case.

\section{CONCLUSION}

In conclusion, although certain key questions remain unanswered, based on our experience and the enormous amount of available literature, the efficacy and safety of ECT is well established for many selected psychiatric conditions, including major depression with psychotic or catatonic features and bipolar disorder during either a depressive or a manic episode. However, the effects of ECT in both psychosis and anxiety disorders is limited. Therefore, before deciding to order ECT as a therapeutic method for these conditions, the possible diagnoses for the patient and the severity of the presenting illness, the patient's treatment history, the efficacy and duration and onset of action, and the expected side effects should be meticulously considered.
3. Greenberg RM, Kellner CH. Electroconvulsive therapy: a selected review. Am J Geriatr Psychiatry. 2005;13:268-81.

4. Pande AC, Grunhaus LJ, Haskett RF, Greden JF. Electroconvulsive therapy in delusional and non-delusional depressive disorder. J Affect Disord. 1990;19:215-9. 
5. Montgomery JH, Vasu D. The use of electroconvulsive therapy in atypical psychotic presentations: a case review. Psychiatry. 2007;4:30-9.

6. Pandra M, Pozuela L, Malone D. Electroconvulsive therapy: what the internist needs to know. Cleve Clin J Med. 2007;74:679-85.

7. Grover S, Mattoo SK, Gupta N. Theories on mechanism of action of electroconvulsive therapy. German J Psychiatry. 2005;8:70-84.
8. McDonald WM, McCall WV, Epstein CM. Electroconvulsive therapy sixty years of progress and a comparison with transcranial magnetic stimulation and vagal nerve stimulation. Neuropsychopharmacology The Fifty Generation of Progess. 1098-108.

9. Nutt DJ, Malizia AL. Next insight into the role of the GABA(A)benzodiazepine receptor in psychiatric disorder. Br J Psychiatry. 2001;179:390-6. 